\title{
Effect of various fire retardant chemicals in different concentrations on formaldehyde emission of plywood
}

\author{
Aydın DEMİ*, İsmail AYDIN, Semra ÇOLAK \\ Karadeniz Technical University, Faculty of Forestry, Department of Forest Industry Engineering, \\ Trabzon, TURKEY \\ *Corresponding author: aydindemir@ktu.edu.tr
}

Received Date: 03.01.2017

Accepted Date: 13.11.2017

Abstract

Aim of study: Although treated panels make up a large portion of the plywood market, treatment with some wood preservatives has been known to cause some problems such as bonding failures besides the environmental pollution related to the disposal of chemicals after treatment. Formaldehyde release from wood based panels is also another problem regarding the indoor air quality. In the present study, it was aimed to investigate the formaldehyde emission contents of plywood panels treated with fire retardant chemicals.

Area of study: This study was conducted at the Pilot Facility of Department of Forest Industry Engineering, Karadeniz Technical University in Trabzon, Turkey.

Material and Methods: Poplar, alder and Scots pine veneers were used to produce plywood. Zinc borate, monoammonium phosphate and ammonium sulfate were used as fire retardant chemicals. The veneer sheets were treated with immersion method and chosen three different concentrations as 5\%,7\% and 10\% aqueous solutions. Urea formaldehyde (UF) glue resin was used as adhesive. Formaldehyde emission contents of plywood panels were determined according to flask method described in DIN EN 717-3 standard.

Main results: It was found that formaldehyde release from panels produced with the veneers treated with zinc borate were higher than those of control panels and the emission values increased when the concentration increased. The lower formaldehyde emission values were obtained for monoammonium phosphate and ammonium sulfate treated panels and the emission values decreased when the concentration increased.

Research highlights: In some usage areas where high strength properties are not expected, plywood panels manufactured from veneers treated with the fire retardant chemicals (monoammonium phosphate and ammonium sulfate) may be used for reducing formaldehyde release.

Keywords: Formaldehyde emission, Plywood, Concentration, Fire retardant, UF

\section{Farklı konsantrasyonlardaki çeşitli yangın geciktirici kimyasalların kontrplakların formaldehit emisyonu üzerine etkisi}

Özet

Çalışmanın amacı: Emprenyeli levhalar, kontrplak piyasasında geniş bir yer edinmelerine rağmen, bazı ahşap koruyucularla emprenye işlemi, yapışma kusurları, emprenye sonrası kimyasal atıklarından dolayı oluşan çevre kirliliği gibi bazı problemlere sebep olduğu bilinmektedir. Ahşap esaslı levhalardan açığa çıkan formaldehit, iç mekanların hava kalitesinde etkili olan başka bir problemdir. Bu çalışmada, yangın geciktirici kimyasallar ile emprenye edilmiş kontrplak levhalarının formaldehit emisyonu miktarlarının araştırılması amaçlanmıştır.

Çalışma alanı: Bu çalışma, Trabzon'daki Karadeniz Teknik Üniversitesi Orman Endüstri Mühendisliği Bölümü Pilot tesisinde yapılmıştır.

Materyal ve Yöntem: Kavak, kızlağaç ve sarıçam (Pinus sylvestris L.) kaplamalar, kontrplak için kullanılmıştır. Çinko borat, monoamonyum fosfat ve amonyum sülfat, yangın geciktirici olarak kullanılmıştır. Kaplama levhaları, $\% 5,7$ ve 10 olmak üzere üç farklı çözelti konsantrasyonu seçilmiş ve daldırma yöntemi kullanılarak emprenye edilmiş̧ir. Kontrplak levhalarının formaldehit emisyonu miktarları, DIN EN 717-3 standardında belirlenen şişe yöntemine göre belirlenmiştir.

Sonuçlar: Çinko borat ile emprenye edilmiş kaplamalardan üretilen kontrplak levhalardan açığa çıkan formaldehit kontrol gruplarından daha yüksek bulunmuştur ve emisyon değerlerinin, konsantrasyon arttıkça arttı̆̆ belirlenmiştir. En düşük formaldehit emisyon değerleri, monoamonyum fosfat ve amonyum sülfat ile emprenye edilmiş levhalardan elde edilmiştir ve emisyon değerlerinin, konsantrasyon arttıkça azaldığı belirlenmiştir.

Araşttrma vurguları: Yüksek direnç özelliklerinin aranmadığı bazı kullanım yerlerinde, formaldehit emisyonunu azaltmak için yangın geciktirici kimyasallarla (monoamonyum fosfat ve amonyum sülfat) emprenye edilen kaplamalardan üretilen kontrplak levhaları kullanılabilir.

Anahtar Kelimeler: Formaldehit emisyonu, Kontrplak, Konsantrasyon, Yangın geciktirici, ÜF 


\section{Introduction}

Plywood is one of the main products that can be used as structural material and has traditionally played an important role in light frame construction. Plywood and other wood-based products are widely used in the manufacture of furniture, engineered flooring, housing, and other industrial products (Bohm, Salem Srba., 2012, p. 221). However, the usage and application areas of plywood are limited since the plywood is a flammable material. Therefore, there has been much interest in the fire-retardanttreatment of wood-based panels (Cheng \& Wang, 2011, p. 1715). The use of plywood treated with fire retardants is becoming popular. They are very important for specialized construction applications and furniture industry (Tanritanir \& Akbulut, 1999, p. 122; Winandy, 2001, p. 47; Ayrilmis, Korkut, Tanritanir, Winandy \& Hiziroglu, 2006, p. 888).

Fire retardant-treated wood products provide a viable alternative to traditional non-combustible materials where a higher level of fire safety is desirable or necessary (White \& Mitchell, 1992, p. 250). Boron compounds are often considered good fire retardants because of their beneficial effects such as preservative effectiveness, neutral $\mathrm{pH}$, and less impact on mechanical properties than some other fire retardant chemicals (Levan \& Tran, 1990, p. 39). Phosphoruscontaining chemicals such as mono- and diammonium phosphates are also known as strong fire retardants, and they have been used for wood and wood-based materials for many years (Grexa, Horvathova, Besinova \& Lehocky, 1999, p. 529).

Formaldehyde is a potential human carcinogen and, due to its high risk level, it is classified differently than most other pollutants (Salem, Zeidler, Böhm, \& Srba, 2013, p. 1200). Also, this chemical has adverse health effects such as eye and respiratory irritation, irritability, inability to concentrate and sleepiness (Milota, 2000, p. 10-9; Colak \& Colakoglu, 2004, p. 533). The most important man-made source of formaldehyde is automotive exhaust that are not fitted with catalytic converters. Formaldehyde is also produced industrially in large quantities and used in many applications. The major anthropogenic sources affecting humans in the indoor environment are products containing formaldehyde such as resins, glues, insulating materials, oriented strand board (OSB), plywood, and fabrics (Uchiyama, Matsushima, Kitao, Tokunaga, Andoc \& Otsuboa, 2007, p. 8825). As wood-based panels are possible sources of formaldehyde emissions, during recent years, a lot of work has evaluated the effects of press conditions (press temperature and time), mat moisture content lower-molecular-weight UF resins, and the addition of formaldehyde scavengers on formaldehyde emissions, and investigated the manufacture of various wood-based panels using low-formaldehyde and nonformaldehyde resins (Minemura, 1976, p. 8; Hao \& Liu, 1993, p. 2; Grigoriou, 2000, p. 34; Wiglusz, Nikei, Igielska \& Sitko, 2002, p. 108; Wang, Gardner \& Baummann 2003, p. 65; Aydin, Colakoglu, Colak \& Demirkir, 2006, p. 1311; Wang, Yang, Lin, Lin \& Tsai, 2007, p. 2472; Wang, Zhao, Gao \& Guo, 2012, p. 1972). Moreover, it was reported that plywood made by adding borax $\left(\mathrm{Na}_{2} \mathrm{~B}_{4} \mathrm{O}_{7} 10-\mathrm{H}_{2} \mathrm{O}\right)$ (Colak \& Colakoglu, 2004, p. 533) and polyvinyl acetate (Kim \& Kim, 2005, p. 456) to the glue mixture exhibited reduced formaldehyde emission. It has also been reported that laminating woodbased composite panel surfaces with decorative vinyl film and melamineimpregnated paper reduces formaldehyde emissions (Groah, Gramp \& Trant, 1984, p. 27; Nemli \& Colakoglu, 2005, p. 83). Also, studies have been made with tannin extracted from the bark of wattle (Vazquez, Freire, Gonzalez \& Antorrena, 2000, p. 57; Kim, Lee, Hyun-Joong \& Hyoung, 2003, p. 1863; Santana, Baumann \& Conner, 1995, p. 146; Pizzi \& Scharfetter, 1978, p. 1745), acacia (Pizzi, 2000, p. 277; Jahanshahee, Tabarsa, Asghari \& Resalati, 2010, p. 27; Jahanshahee, Tabarsa \& Asghari 2012, p. 296) and starch (Farag, 1995, p. 192; Yoshida, Okabe, Yao, Shiraishi \& Oya 2005, p. 335; Turunen, Alvila, Pakkanen \& Rainio, 2003, p. 582; Basta, El-saied, Gobran \& Sultan, 2006, p. 325), mangrove (Sowunmi, Ebewele, Peters \& Conner, 2000, p. 574) in co-condensed resins with phenol and formaldehyde. 
In the past, the important criteria for assessing a wood adhesive for a specific application were its technical properties, gluing behaviour, and cost. During recent years, a new set of criteria has attained more and more importance: the environmental and health aspects of the adhesive itself (Aydin et. al., 2006, p. 1312).

However, few published papers describing techniques for reducing formaldehyde emissions as an environmental pollutant from wood-based panels such as plywood are available. In this study, the effect of various fire retardant chemicals in different concentrations on formaldehyde emission of plywood panels was investigated.

\section{Material and Methods}

In this experimental study, 2 mm-thick rotary cut veneers with the dimensions of $500 \mathrm{~mm}$ by $500 \mathrm{~mm}$ were obtained from poplar (Populus deltoides I-77/51 clone), alder (Alnus glutinosa subsp. barbata) and Scots pine (Pinus sylvestris L.) logs. While the alder and poplar veneers were manufactured from freshly cut logs, Scots pine $\operatorname{logs}$ were steamed for $12 \mathrm{~h}$ before veneer production. The horizontal opening between knife and nosebar was $85 \%$ of the veneer thickness, and the vertical opening was $0.5 \mathrm{~mm}$ in rotary cutting process. The veneers were then dried to $6-8 \%$ moisture content with a veneer dryer. After drying, veneer sheets were treated with some fire retardant chemicals. For this aim, 5, 7 and $10 \%$ aqueous solutions of zinc borate, monoammonium phosphate (MAP) and ammonium sulfate were used. The veneers were subjected to re-drying process at $110^{\circ} \mathrm{C}$ after they immersed in the fire retardant solutions for $20 \mathrm{~min}$. The retention level for each treatment solution was calculated with the following equation, and they were presented in Table 1 .

$$
\mathrm{R}=\frac{\mathrm{G} \times \mathrm{C}}{\mathrm{V}} \times 10 \mathrm{~kg} / \mathrm{m}^{3}
$$

where

$\mathrm{R}=$ Retention level $\left(\mathrm{kg} / \mathrm{m}^{3}\right)$

$\mathrm{G}=$ treatment solution absorbed by the sample

$\mathrm{C}=$ preservative or preservative solution in $100 \mathrm{~g}$ treatment solution.

$\mathrm{V}=$ volume of sample in $\mathrm{cm}^{3}$

Table 1. Retention levels of fire retardant chemicals $\left(\mathrm{kg} / \mathrm{m}^{3}\right)$

\begin{tabular}{ccccc}
\hline $\begin{array}{c}\text { Fire Retardant } \\
\text { Chemicals }\end{array}$ & $\begin{array}{c}\text { Aqueous } \\
\text { Solutions (\%) }\end{array}$ & Poplar & Alder & Scots pine \\
\hline \multirow{2}{*}{ Zinc Borate } & 5 & 17.118 & 16.324 & 13.800 \\
& 7 & 20.854 & 20.107 & 19.915 \\
& 10 & 30.243 & 29.053 & 26.420 \\
\hline \multirow{2}{*}{ MAP } & 5 & 11.233 & 10.233 & 12.689 \\
& 7 & 14.219 & 14.595 & 18.033 \\
Ammonium Sulfate & 10 & 19.514 & 18.601 & 23.402 \\
\hline & 5 & 9.705 & 9.781 & 11.578 \\
& 7 & 11.594 & 11.350 & 17.553 \\
& 10 & 14.660 & 15.254 & 24.993 \\
\hline
\end{tabular}

Three-ply-plywood panels with $6 \mathrm{~mm}$ thick were manufactured by using urea formaldehyde resin. The formulations of adhesive mixtures used for plywood manufacturing are given in Table 2. Veneers sheets were conditioned to approximately $5-$ 7\% moisture content in a climatization chamber before gluing. The glue mixture was applied at a rate of $160 \mathrm{~g} / \mathrm{m}^{2}$ to the single surface of veneer by using a four-roller glue spreader. Hot press pressure was $12 \mathrm{~kg} / \mathrm{cm}^{2}$ for alder and $8 \mathrm{~kg} / \mathrm{cm}^{2}$ for scots pine and poplar panels while hot pressing time and temperature were $6 \mathrm{~min}$ and $110^{\circ} \mathrm{C}$, respectively. Two replicate panels were manufactured for each test groups. 
Table 2. The formulations of UF glue mixture used for the manufacturing of plywood

\begin{tabular}{lll}
\hline Glue Type & Ingredients of Glue Mixture & Parts by weight \\
\hline & UF resin & 100 \\
(with 55\% solid content) & 30 \\
WF & $\begin{array}{l}\text { Wheat flour } \\
\text { Hardener }-\mathrm{NH}_{4} \mathrm{Cl}\end{array}$ & 10 \\
\hline
\end{tabular}

Formaldehyde emission contents of plywood panels were determined according to flask method described in DIN EN 717-3 standard. This is a simple and inexpensive method for testing formaldehyde release and suitable for testing of uncoated boards (Aydin et. al., 2006, p. 1313). In this method; test pieces of known mass is suspended over water in a closed container at constant temperature. The formaldehyde released from the test pieces is absorbed by the water and determined photometrically (Sundman, Larsen, Vestin \& Weibull, 2007, p. 3195). The temperature and time were applied as $40^{\circ} \mathrm{C}$ and $3 \mathrm{~h}$, respectively in determining the formaldehyde emission. The test apparatus shown in Figure 1 was used for the determination of formaldehyde release from plywood panels.

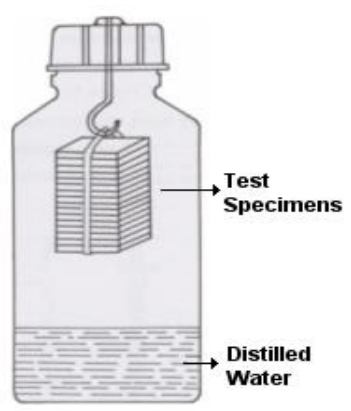

Figure 1. Test apparatus used for the determination of formaldehyde emission content of plywood panels.

\section{Results and Discussion}

Formaldehyde emission test results according to wood species were presented in Table 3.

Table 3. Formaldehyde emission contents of plywood panels (mg/100g oven dry panel)

\begin{tabular}{ccccc}
\hline $\begin{array}{c}\text { Fire } \\
\text { Retardant } \\
\text { Chemicals }\end{array}$ & $\begin{array}{c}\text { Aqueous } \\
\text { Solutions } \\
(\%)\end{array}$ & Poplar & Alder & Scots pine \\
\hline \multirow{2}{*}{ Zinc Borate } & Control & 1.020 & 0.697 & 1.158 \\
\cline { 2 - 5 } & 5 & 1.404 & 1.121 & 1.600 \\
MAP & 7 & 1.523 & 1.249 & 1.620 \\
& 10 & 1.614 & 1.251 & 1.796 \\
\hline \multirow{2}{*}{ Ammonium Sulfate } & 5 & 0.516 & 0.392 & 0.571 \\
& 7 & 0.498 & 0.273 & 0.533 \\
& 10 & 0.434 & 0.249 & 0.532 \\
\hline
\end{tabular}

As can be seen from Table 3, Scots pine plywood panels had the highest formaldehyde release whereas the lowest formaldehyde emission content was found alder. The treatment processes with fire retardant chemicals evidently affected the formaldehyde emissions of the panels.
Monoammonium phosphate and ammonium sulfate showed a decreasing effect on the formaldehyde emissions, whereas zinc borate showed an increasing effect. The formaldehyde emission of panels treated with zinc borate increased while its of panels treated with monoammonium phosphate and 
ammonium sulfate decreased with increasing concentration. The lowest formaldehyde emission values were obtained for plywood treated with monoammonium phosphate. Treatment with monoammonium phosphate decreased the formaldehyde emission values of the panels produced from treated veneers by 49,51 and $57 \%$ for poplar, 44, 61 and $64 \%$ for alder, 51, 54 and 54\% for Scots pine panels treated 5, 7 and $10 \%$ in aqueous solutions, respectively.

In this study, the ammonia released from monoamonium phosphate and ammonium sulfate could produce N-H functional groups on the surface of the veneer sheets which help to reduce the formaldehyde emission (Zhang, Liu \& Lu, 2013, p. 607; Schroder Meyer-Plath, Keller, Besch, Babucke \& Ohl 2001, p. 562; Wen, Yang, Ou, Wu, Chou, Luo \& Chang, 2006, p. 3166). Zhang et al. (2013) found for plywood panels that formaldehyde emission values decreased with cold-ammonia plasma pretreated veneer sheets. Some studies have also indicated that when wood treated with ammonium acetate solution, the formaldehyde emission from the wood composites reduced (Colak, Colakoglu, Testereci \& Aydin, 2002; Myers, 1986, p. 41). Aydin (2004) stated that the ammonium acetate behaves as a formaldehyde scavenger especially when urea-formaldehyde glue was used as adhesive in the manufacturing of wood composites. In addition, Junyou and Shengyou (2010) found the formaldehyde emission from poplar plywood was significantly decreased with addition of ammonia. Wang et al. (2012) stated that combinations of ammonia and sodium sulfite as formaldehyde scavengers had positive effects on the formaldehyde emission of plywood panels. The zinc borate used in this study increased the formaldehyde emission of the all wood species. Colak and Colakoglu (2004) found the boric acid increased the formaldehyde emissions of the panels. In previous study, it was also found that zinc borate had an increasing effect on formaldehyde emission of plywood (Demir, Aydin \& Ozturk, 2014, p. 63).

\section{Conclusion}

This study investigated effect of fire retardant chemicals on the formaldehyde emission of plywood panels. As a result of this study; formaldehyde emission contents of the panels produced from veneers treated with zinc borate were found to be higher than those of the control panels while the lower formaldehyde emission values were obtained for monoammonium phosphate and ammonium sulfate treated panels when compared to the control panels. The formaldehyde emission of panels treated with zinc borate increased while its of panels treated with monoammonium phosphate and ammonium sulfate decreased with increasing concentration. Treatment of monoammonium phosphate and ammonium sulfate caused considerable reduction in formaldehyde emission from manufactured plywood panels. In some usage areas where high strength properties are not expected, plywood panels manufactured from veneers treated with them may be used for reducing formaldehyde release.

\section{Acknowledgement}

This study was presented in International Forestry Symposium in University of Kastamonu, 2016.

\section{References}

Aydin, I. (2004). Effects of some manufacturing conditions on wettability and bonding of veneers obtained from various wood species. $\mathrm{PhD}$ thesis, KTU Graduate School of Natural and Applied Sciences, 219 p., Trabzon.

Aydin I., Colakoglu, G., Colak, S. \& Demirkir, C. (2006). Effects of moisture content on formaldehyde emission and mechanical properties of plywood. Building and Environment, 41, 13111316. doi: 10.1016/j.buildenv.2005.05.011.

Ayrilmis, N., Korkut, S., Tanritanir, E., Winandy, J.E. \& Hiziroglu, S. (2006). Effect of various fire retardants on surface roughness of plywood. Building and Environment 41(7), 887-892. doi: doi:10.1016/j.buildenv.2005.04.011.

Basta, A.H, El-saied, H., Gobran, R.H. \& Sultan M.Z. (2006). Enhancing environmental performance of formaldehyde- based adhesives in lignocellulosic composites, part III: 
evaluation of some starch derivatives. Des. Monomers Polymers, 9, 325-347. doi: 10.1108/03699420510572557.

Bohm, M., Salem, M.Z.M. \& Srba, J. (2012). Formaldehyde emission monitoring from a variety of solid wood, plywood, blockboard and flooring products manufactured for building and furnishing materials. Journal of Hazardous Materials, 221-222, 68-79. doi: 10.1016/j.jhazmat.2012.04.013.

Cheng, R. X., \& Wang, Q. W. (2011). The influence of FRW-1 fire retardant treatment on the bonding of plywood. Journal of Adhesion Science and Technology, 25(14), 1715-1724. doi: 10.1163/016942410X549951.

Colak, S., Colakoglu, G., Testereci, H. \& Aydin, I. (2002). Formaldehyde and volatile acetic acid emission of plywood treated with ammonium acetate. Paper presented at the sixth european panel products symposium, North Wales Conference Centre, Llandudno, North Wales, UK.

Colak, S. \& Colakoglu, G. (2004). Volatile acetic acid and formaldehyde emission from plywood treated with boron compound. Building and Environment, 39, 533-536. doi: 10.1016/j.buildenv.2003.08.019.

DIN EN 717-3, 1996. Wood-based panel products - Determination of formaldehyde release by the flask method.

Demir, A., Aydin, İ. \& Öztürk H. (2014). Effect of fire retardant chemicals on formaldehyde emission of plywood. $25^{\text {th }}$ International Scientific Conference New Materials and Technologies in the Function of Wooden Products (17 October), 63-66, Zagreb, Croatia.

Farag, S. (1995). Synthesis and physicochemical studies of starchsulphonated phenol formaldehyde cationic exchangers. Starch-Starke, 47, 192-196. doi: 10.1002/star.19950470507.

Grexa, O., Horvathova E., Besinova, O. \& Lehocky, P. (1999). Flame retardant plywood. Polymer Degradation and Stability, 64, 529-33. doi: 10.1016/S0141-3910(98)00152-9.

Grigoriou, A.H. (2000). Straw-wood composites bonded with various adhesive systems. Wood Science and Technology 34, 355-365. doi: $10.1007 / \mathrm{s} 002260000055$.

Groah, W.J., Gramp, G.D. \& Trant, M. (1984). Effect of a decorative vinyl overlay on formaldehyde emissions. Forest Products Journal, 34, 27-29.

Hao, B.Y. \& Liu, Z.T. (1993). The primary study on straw particleboard. Wood Industry 7(3), 2-6.

Jahanshahee, Sh., Tabarsa, T., Asghari, J. \& Resalati, H. (2010). Investigation of the amount of tannic acid in Bark Oak (Quercus castanifolia). Iranian Journal of Wood and Paper Industries, 2, 27-35.

Jahanshahee, Sh., Tabarsa, T. \& Asghari, J. (2012). Eco-friendly tannin-phenol formaldehyde resin for producing wood composites. Pigment \& Resin Technology, 41, 296-301. doi: $10.1108 / 03699421211264857$.

Junyou, S. \& Shengyou, Y. (2010). Effects of addition ammonia modified ureamelamine -formaldehyde resin on the adhesions and formaldehyde emission in plywood. Environment Materials and Environment Management PTS 1-3. Book Series: Advanced Materials Research, 113-116, 1226-1229.

Kim, S., Lee, Y.K., Hyun-Joong, K. \& Hyoung, L.H. (2003). Physicomechanical properties of particleboards bonded with pine and wattle tannin-based adhesives. Journal of Adhesion Science and Technology, 17, 1863-1875. doi: $10.1163 / 156856103770572025$.

Kim, S. \& Kim, H.J. (2005). Effect of addition of polyvinyl acetate to melamine-formaldehyde resin on the adhesion and formaldehyde emission in engineered flooring. International Journal of Adhesion and Adhesives, 25, 456-461. doi: 10.1016/j.ijadhadh.2005.01.001.

Levan, S.L. \& Tran, H.C. 1990. The role of boron in flame-retardant treatments. In: Hamel M, editor. First international conference on wood protection with diffusible Preservatives (28-30 November), 39-41, Nashville, TN.

Milota, M.R. (2000). Emissions from wood drying. Forest Product Journal, 50(6), 10-9. 
Minemura, N. (1976). To lessen formaldehyde liberation from the urea resin glued plywood. Wood Industry, 31(12), 8-12.

Myers, G.E. (1986). Effects of postmanufacture board treatments on formaldehyde emission: A literature review (1960-1984). Forest Products Journal, 36(6), 41-45.

Nemli, G. \& Colakoglu, G. (2005). The influence of lamination technique on the properties of particleboard. Building and Environment, 40, 83-87. Doi: 10.1016/j.buildenv.2004.05.007.

Pizzi, A. \& Scharfetter, H.O. (1978). The chemistry and development of tannin based adhesives for exterior plywood's. Journal of Applied Polymer Science, 22, 1745-1761.

doi: 10.1002/app.1978.070220623.

Pizzi, A. (2000). Tannery row - the story of some natural and synthetic wood adhesives. Wood Science Technology, 48, 277-316. doi: 10.1007/s002260000052.

Salem, M.Z.M., Zeidler, A., Böhm, M. \& Srba, J. (2013). Norway spruce (Picea abies [L.] Karst.) as a bioresource: Evaluation of solid wood, particleboard, and MDF technological properties and formaldehyde emission. BioResources, $8(1), 1199-1221$.

Santana, M.A.E., Baumann, M.G.D. \& Conner, A.H. (1995). Resol resins prepared with tannin liquefied in phenol. Holzforschung, 49, 146-152. doi: 0.1515/hfsg. 1995.49.2.146.

Sundman, M.R., Larsen, A., Vestin, E. \& Weibull, A. (2007). Formaldehyde emission-Comparison of different standard methods. Atmospheric Environment, 41, 3193-3202. doi: 10.1016/j.atmosenv.2006.10.079.

Uchiyama, S., Matsushima, E., Kitao, N., Tokunaga, H., Andoc, M. \& Otsuboa, Y. (2007). Effect of natural compounds on reducing formaldehyde emission from plywood. Atmospheric Environment, 41, 8825-8830.

doi: 10.1016/j.atmosenv.2007.09.046.

Sowunmi, S., Ebewele, R.O., Peters, O. \& Conner A.H. (2000). Differential scanning calorimetry of hydrolysed mangrove tannin. Polymer International, 49, 574-578.

Schroder, K., Meyer-Plath, A., Keller, D., Besch, W., Babucke, G. \& Ohl, A. (2001). Plasma-induced surface functionalization of polymeric biomaterials in ammonia plasma. Contributions to Plasma Physics, 41(6), 562-572. doi: 10.1002/15213986(200111)41:6<562::AI DCTPP562>3.0.CO;2-Y.

Tanritanir, E. \& Akbulut, T. (1999). Plywood industry and general situation of plywood trade. Laminart-Furniture and Decoration Journal, 9, 122-32.

Turunen, M., Alvila, L., Pakkanen, T.T. \& Rainio, J. (2003). Modification of phenolformaldehyde resol resins by lignin, starch, and urea. Journal of Applied Polymer Science, 88, 582-588. doi: 10.1002/app.11776.

Vazquez, G., Freire, S., Gonzalez, J. \& Antorrena, G. (2000). Characterization of Pinus pinaster bark and its alkaline extracts by diffuse reflectance Fourier transform infrared (DRIFT) spectroscopy. Holz als Roh-und Werkstoff, 58, 57-61. doi: 10.1007/s001070050387.

Wang, W., Zhao, Z., Gao, Z. \& Guo, M. (2012). Water-resistant whey protein based wood adhesive modified by posttreated phenol-formaldehyde oligomers (PFO). BioResources. 7(2), 1972-1983.

Wang, S.Y., Yang, T.H., Lin, Y.T., Lin, C.J. \& Tsai, M.J. (2007). Properties of lowformaldehyde-emission particleboard made from recycled wood-waste particles sprayed with PMDI/PF resin. Building and Environment, 42(7), 2472-2479. doi: 10.1016/j.buildenv.2006.06.009.

Wang, W.L., Gardner, D.J. \& Baummann, M.G.D. (2003). Factors affecting volatile organic compound emissions during hotpressing of southern pine particleboard. Forest Products Journal, 53(3), 65-72.

Wen, H.C., Yang, K., Ou, K.L., Wu, W.F., Chou, C.P., Luo, R.C. \& Chang, Y.M. (2006). Effects of ammonia plasma treatment on the surface characteristics of carbon fibers. Surface and Coatings Technology, 200(10), 3166-3169. doi: 10.1016/j.surfcoat.2005.07.036. 
White, R.H. \& Mitchell, S.S. (1992). Flame retardancy of wood: present status, recent problems, and future fields. In: Lewin M, editor. Recent advances in flame retardancy of polymeric materials. Proceedings of the third annual BCC conference on flame retardance, p. 250257, Stamford, CT.

Wiglusz, R., Nikei, G., Igielska, G. \& Sitko, E. (2002). Volatile organic compounds emissions from particleboard veneered with decorative paper foil. Holzforschung, 56(1), 108-110. doi: 10.1515/HF.2002.018.
Winandy, J.E. (2001). Thermal degradation of fire-retardant-treated wood: predicting residual service life. Forest Products Journal, 51(2), 47-54.

Yoshida, C., Okabe, K., Yao, T., Shiraishi, N. \& Oya, A. (2005). Preparation of carbon fibers from biomass-based phenol formaldehyde resin. Journal of Materials Science, 40, 335-339. doi: 10.1007/s10853-005-6087-1.

Zhang, H., Liu, J. \& Lu, X. (2013). Reducing the Formaldehyde Emission of Composite Wood Products By Cold Plasma Treatment. Wood Research, 58(4), 607616. 